\title{
The synthesis and electrochemistry of 2,5-dimethylazaferrocenes with heteroaryl bridges
}

\author{
Konrad Kowalski ${ }^{\mathrm{a}, \mathrm{b}, *}$, Rainer F. Winter ${ }^{\mathrm{b}, *}$ \\ a Department of Organic Chemistry, Faculty of Chemistry, University of Łódź, Narutowicza 68, 90-136 tódź, Poland \\ ${ }^{\mathrm{b}}$ Institut für Anorganische Chemie der Universität Regensburg, Universitätsstraße 31, D-93040 Regensburg, Germany
}

\begin{abstract}
A B S T R A C T
We report on the synthesis of complexes having two equivalent redox active 2,5-dimethylazaferrocenyl entities connected by heteroaryl (heteroaryl = thiophenyl, bithiophenyl and pyridyl) bridges. The new compounds have been investigated by various electrochemical techniques including cyclic voltammetry (CV), differential pulse voltammetry (DPV) and square wave voltammetry (SW) and were found to exhibit two consecutive reversible or partially reversible one-electron oxidations. Comproportionation constants $\left(K_{\mathrm{c}}\right)$ calculated from $\Delta E_{1 / 2}$ values indicate that the thermodynamic stability of their monoxidized forms exceeds those of analogous ferrocenes. In this paper we also report the X-ray crystal structure and UV-Vis spectroelectrochemistry of parent 2,5-dimethylazaferrocene.
\end{abstract}

\section{Introduction}

Homo- and heterobinuclear complexes with $\pi$-conjugated bridges have attracted considerable attention during recent years because they serve as simple models for investigating metal-metal electronic communication [1]. There is also an increasing awareness that such metal capped $\pi$-conjugated systems will play a role in the design of new generations of electronic materials [2]. Ferrocenes, due to the high stabilities of their neutral and oxidized forms, have been extensively explored as electroactive end-groups in that area of research [3]. Compounds with two ferrocenyl units can be divided into two subclasses. The first class is represented by complexes in which the ferrocenyl fragments are equivalent by symmetry. The second one comprises complexes with non-equivalent ferrocenyl sites which is mostly imposed by a low symmetry of the bridging heterocycle(s). 2,5-Di(ferrocenyl)thiophene (1) [4], 3,4-di(ferrocenyl)thiophene (2) [4], 2,6-di(ferrocenyl)pyridine (3) [4], 1,3-di(ferrocenyl)benzo[b]thiophene (4) [5], 1,3-di(ferrocenyl)benzo[b]selenophene (5) [5], 5, $5^{\prime \prime \prime}$-di(ferroce-

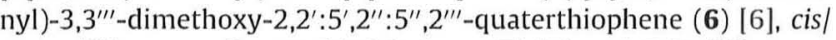
trans di(ferrocenyl)-tetrathiafulvalene (7) [7] and 5,5'-di(ferroce-

* Corresponding authors. Addresses: Department of Organic Chemistry, Faculty of Chemistry, University of Łódź. Narutowcza 68, 90-136 Łódź, Poland (K. Kowalski), Institut für Anorganische Chemie der Universität Regensburg, Universitätsstraße 31, D-93040 Regensburg, Germany (R.F. Winter). Tel.: +48 426355755; fax: +48 426786583 (K. Kowalski), tel.: +49 9414485; fax: +49 9414488 (R.F. Winter).

E-mail addresses: kondor15@wp.pl (K. Kowalski),rainer.winter@chemie.uniregensburg.de (R.F. Winter). nyl)-2,2'-bis(thiazole) (8) [8] (Fig. 1) are representative examples of the first class of complexes.

Derivatives of class two are represented by 2,3-di(ferrocenyl)benzo|b]thiophene (9) [5], 2,5-di(ferrocenyl)thiazole (10) $[8,9]$ and 2,5-di(ferrocenyl)oxazole (11) [10] (Fig. 2).

The degree of interactions between the iron centers in the mixed-valent states of 1-5 has been mostly investigated by cyclic voltammetry (CV). Unfortunately, the different experimental conditions applied hamper a straightforward comparison of the difference between the individual half-wave potentials, $\Delta E_{1 / 2}$, of $\mathbf{1 - 5}$ and of the comproportionation constants $\left(K_{\mathrm{c}}\right)$ derived thereof via Eq. (1) [11]. In Eq. (1), $F$ is the Faraday constant, $n$ the number of transferred electrons and $\Delta E_{1 / 2}$ the difference of half-wave potentials. Nevertheless, the highest $\Delta E_{1 / 2}$ values of $280 \mathrm{mV}$ and $305 \mathrm{mV}$ have been reported for $\mathbf{4}$ and $\mathbf{5}$, respectively, corresponding to $K_{\mathrm{c}}=5.4 \times 10^{4}$ for $\mathbf{4}$ and $K_{\mathrm{c}}=1.4 \times 10^{5}$ for $\mathbf{5}$ [5]. Lower degrees of electronic interactions between the iron centers have been detected (by means of $\mathrm{CV}$ technique) for $1\left(\Delta E_{1 / 2}=150 \mathrm{mV}, K_{\mathrm{c}}=\right.$ 340), $2\left(\Delta E_{1 / 2}=140 \mathrm{mV}, K_{\mathrm{c}}=230\right)$ along with negligible interactions in the case of $\mathbf{3}$ (one two-electron redox wave, $\Delta E_{1 /}$ $2 \approx 0 \mathrm{mV}$ ) [4]. Extensive studies by Tárraga and Molina [8-10] on unsymmetrical di(ferrocenyl) substituted heteroarenes suggest the presence of electronic iron-iron interactions in $\mathbf{1 0}$ and $\mathbf{1 1}$ $\left(\Delta E_{1 / 2}=140 \mathrm{mV}, K_{\mathrm{c}}=2.32 \times 10^{2}\right.$ in each case) but not in $\mathbf{8}$ (one two-electron redox wave, $\Delta E_{1 / 2} \approx 0 \mathrm{mV}$ ). These interactions can be efficiently modulated by protonating the bridging ligands [810 . Moreover, complex $\mathbf{1 0}$ showed dual optical and redox sensor activities toward $\mathrm{Zn}^{2+}, \mathrm{Cd}^{2+}, \mathrm{Hg}^{2+}, \mathrm{Ni}^{2+}$ and $\mathrm{Pb}^{2+}$ cations [8]. These results clearly shown that utilization of ferrocenyl fragments as 
<smiles>Fc1cscc1C(F)F</smiles><smiles>FC(F)(F)F</smiles>

3<smiles>COc1cc(F)sc1-c1ccc(-c2ccc(-c3sc(F)cc3OC)s2)s1</smiles><smiles>FC1=CS/C(=C2\SC=C(F)S2)S1</smiles>

7<smiles>Fc1sc(F)c2ccccc12</smiles><smiles>Fc1sc(C(F)F)c2ccccc12</smiles><smiles>Fc1cnc(-c2ncc(F)s2)s1</smiles>

$\mathrm{Fc}=$ Ferrocene

Fig. 1. Symmetrical heteroaryl bridged diferrocenes.<smiles>Fc1sc2ccccc2c1F</smiles><smiles>Fc1cnc(F)s1</smiles>

10<smiles>Fc1cnc(F)o1</smiles>

11

$\mathrm{Fc}=$ Ferrocene

Fig. 2. Unsymmetrical heteroaryl bridged diferrocenes.

capping groups in heteroaryl bridged dinuclear complexes provides access to their corresponding thermodynamically stable mixed-valence monoxidized forms that exhibit fair levels of $\mathrm{Fe}(\mathrm{II})-\mathrm{Fe}(\mathrm{III})$ electronic interactions

$K_{\mathrm{c}}=\exp \left[(n \cdot F / R \cdot T) \cdot \Delta E_{1 / 2}\right]$

The synthesis of novel bridged metallocenes with a high degree of electron delocalization in their mixed-valence state(s) presents a continuous scientific challenge. With this in mind we here report on the synthesis and electrochemical characterization of the three novel 2,5-dimethylazaferrocenyl substituted derivatives 2,5-di(1'(2,5-dimethylazaferrocenyl))thiophene (12), 2,6-di(1'-(2,5-dimethylazaferrocenyl))pyridine (13) and 5,5'-di(1'-(2,5-dimethylazaferrocenyl))-2,2'-bithiophene (14). Complexes 12 and 13 are close relatives of compounds $\mathbf{1}$ and $\mathbf{3}$. The rationale for introduction of 2,5-dimethylazaferrocene was to investigate the degree of electronic interactions mediated by thiophenyl, bithiophenyl and pyridyl bridges when connected to end-groups with a higher redox potential than that of ferrocene [13].

In this paper we also report the X-ray crystal structure of parent 2,5-dimethylazaferrocene (15) along with the UV-Vis spectroelectrochemical characterization of its associated radical cation.

\section{Results and discussion}

\subsection{Synthesis of 12, 13 and $\mathbf{1 4}$}

Several preparative strategies have successfully been applied to the synthesis of symmetrical heteroaryl bridged diferrocenes. Complexes $\mathbf{4}$ and $\mathbf{5}$ were obtained by three step linear syntheses [5]. The final steps involve formation of the benzo[b]thiophene and benzo[b]selenophene bridging fragments by the ring-closure of ortho diferrocenoylbenzene with Lawesson's reagent or selenating reagents. A simpler strategy toward the synthesis of complex 1 comprises the thermolysis of ethynylferrocene in the presence of mononuclear metal carbonyls and elemental sulfur in benzene solution [12]. However, the most straightforward and universal approach is represented by palladium catalyzed cross-coupling reactions of ferrocenylzinc chloride and dihaloheteroarenes. Based on this methodology, complexes 1, 2, 3, 6, 7 and 9 have been obtained
[4-7]. We have already reported that 2,5-dimethylazaferrocenylzinc chloride undergoes palladium catalyzed cross-coupling reactions with dibromoheteroarenes to yield 1'-heteroaryl-2,5dimethylazaferrocenes [13]. As a logical continuation of this study we applied this type of cross-coupling reactions toward the preparation of symmetrical heteroaryl bridged dinuclear azaferrocenyl complexes.

The synthetic route for the preparation of compounds 12,13 and $\mathbf{1 4}$ is outlined in Scheme 1 and involves lithiation of 2,5-dimethylazaferrocene (15) [14] followed by addition of $\mathrm{ZnCl}_{2}$. In the next step a catalytic amount of $\mathrm{PdCl}_{2}\left(\mathrm{PPh}_{3}\right)_{2}$ in THF and the appropriate reactive $1^{\prime}$-heteroaryl-2,5-dimethylazaferrocenes $\mathbf{1 6}$ [13], 17 [13] or $\mathbf{1 8}$ were successively added at room temperature to the stirring reaction mixtures.

In order to increase the yields, an excess of the readily available 2,5-dimethylazaferrocene was used. It is worth to point out that the bromo-substituted bithiophene derivative $\mathbf{1 8}$ is another example of a new 1'-heteroaryl-2,5-dimethylazaferrocene that was obtained in the course of this work. It was therefore characterized by various spectroscopic techniques and by elemental analysis (see Section 4). Analytically pure samples of 12 and 14 have been obtained after standard workup and crystallization from $n$-hexane with $58 \%$ and $73 \%$ isolated yields. The pyridine derivative 13 has been isolated as orange-red viscous solid in a $61 \%$ yield. All newly synthesized compounds are fairly thermally and air stable. Interestingly, in case of the reaction with $\mathbf{1 6}$ we were able to isolate, besides the expected 12, trace amounts of the bithiophene complex 14 and of debrominated 19 (Fig 3). Similar side reactions were seemingly encountered in the reactions with $\mathbf{1 7}$ and 18. In those cases we also observed upon column chromatography additional small, broad and weakly colored fractions. The ${ }^{1} \mathrm{H}$ NMR spectra of these fractions indicated the presence of complex mixtures of still unseparated products.

The structures of 12, 13 and 14 were confirmed by spectroscopic methods and elemental analyses. The ${ }^{1} \mathrm{H}$ NMR spectrum of 12 shows a singlet at $6.96 \mathrm{ppm}$ for the two equivalent thienyl ring protons, two four protons singlets at $4.50 \mathrm{ppm}$ and $4.31 \mathrm{ppm}$ for the substituted cyclopentadienyl ligands, a singlet at $4.27 \mathrm{ppm}$ for the $\beta$-pyrrolyl protons and a singlet at $2.12 \mathrm{ppm}$ from the four $\alpha$-pyrrolyl methyl groups. The ${ }^{1} \mathrm{H}$ NMR spectrum of $\mathbf{1 3}$ exhibits a low-field one proton triplet at $7.59 \mathrm{ppm}$ and a two protons doublet at $7.30 \mathrm{ppm}$. This pattern clearly indicates the presence of a symmetrical 2,6-disubstituted pyridine ring. The two triplets of the cyclopentadienyl ligands' protons appear at $4.93 \mathrm{ppm}$ and $4.40 \mathrm{ppm}$, along with a four protons singlet at $4.24 \mathrm{ppm}$ for the $\beta$-pyrrolyl protons and a singlet at $2.03 \mathrm{ppm}$ from the four $\alpha$-pyrrolyl methyl groups. The ${ }^{1} \mathrm{H}$ NMR spectrum of 14 shows two doublets at $7.03 \mathrm{ppm}$ and $6.99 \mathrm{ppm}$ for the two pairs of nonequivalent thienyl protons, two four protons singlets at $4.51 \mathrm{ppm}$ and $4.33 \mathrm{ppm}$ for the substituted cyclopentadienyl ligands, a 

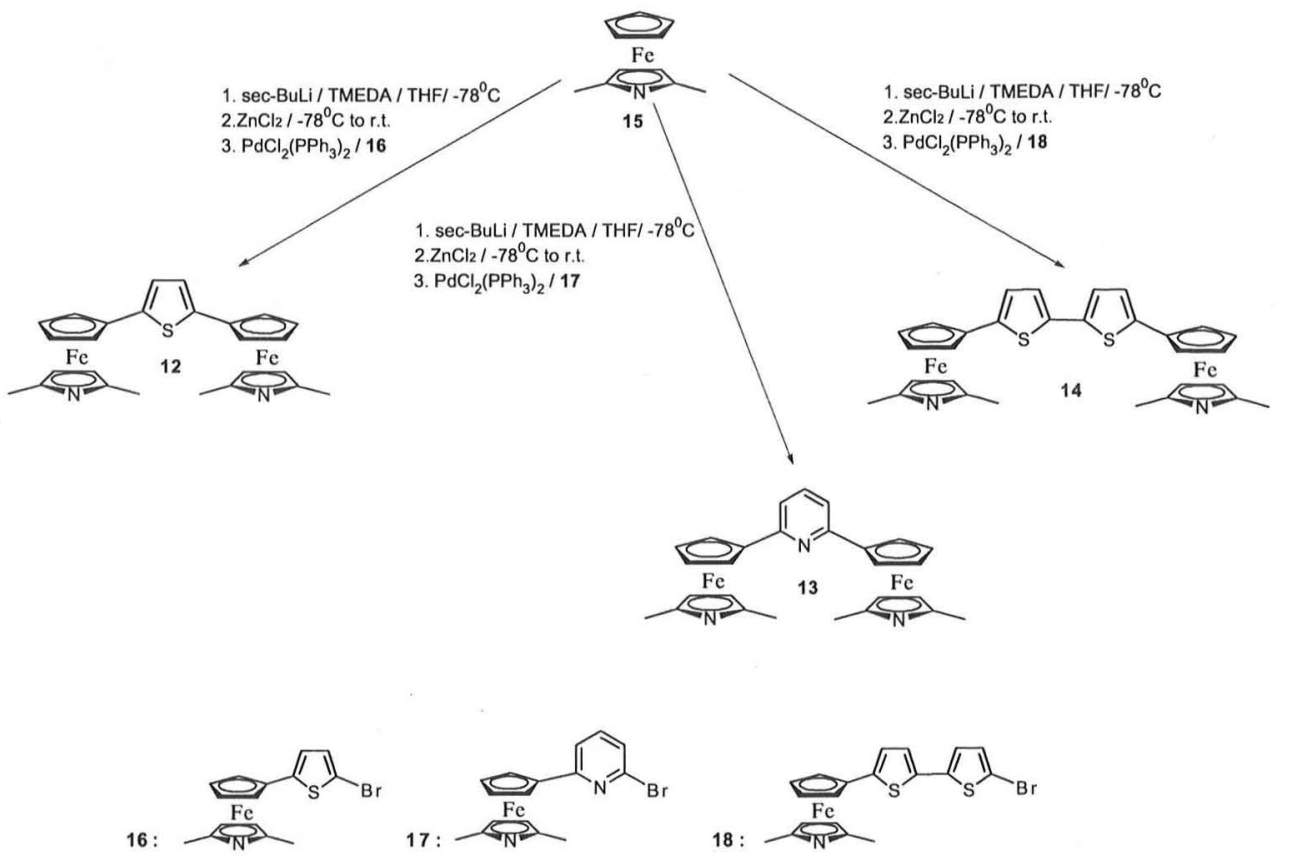

Scheme 1. Synthesis of compounds 12, 13 and 14.

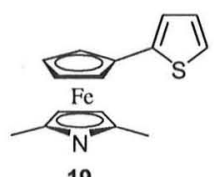

19

Fig. 3. The structure of byproduct 19.

singlet at $4.29 \mathrm{ppm}$ for the $\beta$-pyrrolyl protons and a singlet at $2.14 \mathrm{ppm}$ from the four $\alpha$-pyrrolyl methyl groups.

\subsection{Electrochemical studies of $\mathbf{1 2}, \mathbf{1 3}, \mathbf{1 4}$ and $\mathbf{1 8}$}

One important incentive for preparing heteroaryl bridged dinuclear 2,5-dimethylazaferrocenes $\mathbf{1 2}, 13$ and $\mathbf{1 4}$ was to investigate their electrochemical behavior, especially with respect to electronic communication between the iron centers. It was of particular interest to compare the thermodynamic stabilities $\left(K_{\mathrm{c}}\right.$ values, Eq. (1)) of their mixed-valent radical cations to those of the analogous ferrocenes $\mathbf{1}$ and $\mathbf{3}$ and to that of the closely related $\mathbf{8}$.

Electrochemical studies on the heteroaryl bridged 2,5-dimethylazaferrocene derivatives $\mathbf{1 2}, 13$ and $\mathbf{1 4}$ and on the azaferrocenyl substituted bithiophene $\mathbf{1 8}$ were conducted in $\mathrm{CH}_{2} \mathrm{Cl}_{2} / \mathrm{NBu}_{4} \mathrm{PF}_{6}$ $(0.2 \mathrm{M})$ at $293 \mathrm{~K}$. The choice of this supporting electrolyte follows our recent observation [13] that the 0/+ couple of parent 2,5-dimethylazaferrocene is considerably more reversible in this electrolyte when compared to $\mathrm{CH}_{2} \mathrm{Cl}_{2} / \mathrm{NBu}_{4} \mathrm{ClO}_{4}$ [15]. Under these conditions, all heteroaryl bridged 2,5-dimethylazaferrocenes displayed two consecutive closely to moderately spaced one-electron oxidations. While the radical cations appear to be stable on the voltammetric time-scale, dioxidized $12^{2+}$ and $\mathbf{1 3}^{2+}$ are not. Overall reversibility coefficients as they were calculated by the ratio of the total cathodic reverse and the anodic forward currents $i_{\mathrm{p}, \mathrm{rev}} / i_{\mathrm{p} \text {,forw }}$ are 0.9 in the case of 12 and 0.85 for $\mathbf{1 3}$ at $v=0.1 \mathrm{~V} / \mathrm{s}$ but steadily increase to approach 1.0 as the sweep rate is increased to $1.0 \mathrm{~V} / \mathrm{s}(\mathbf{1 2})$ or $2.0 \mathrm{~V} / \mathrm{s}$ (13) or upon cooling. No such complications were observed for 14.
As it is apparent from the cyclic voltammograms and square wave voltammograms in Fig. 4 and the data in Table 1, the splitting of half-wave potentials, $\Delta E_{1 / 2}$, and $K_{c}$ values increase in the order $13<14<12$. In lieu of a direct measure of the degree of electronic coupling, e.g. by the analysis of electronic intervalence charge transfer bands of the associated radical cations (vide infra), it is not clear whether this trend also mirrors an increase of "communication" across the bridge. While there are several examples of such correlations between $\Delta E_{1 / 2}\left(K_{\mathrm{C}}\right)$ and the electronic coupling element $V_{\mathrm{AB}}$ (or a parameter directly related to $V_{\mathrm{AB}}$ ) $[16,17]$ in the literature, [18] there are also adverse cases where such correlations do not exist [19]. We nevertheless note that the $\Delta E_{1 / 2}$ values of 12 and 13 (and consequently their $K_{\mathrm{c}}$ values) are consistently larger than those of the analogous ferrocene derivatives $\mathbf{1}$ and $\mathbf{3}$. One may speculate that this arises from the lower energy gap between the azaferrocene based "redox orbitals" and those of the respective bridge. Thus, 2,5-dimethylazaferrocene is oxidized $170 \mathrm{mV}$ positive of the $\mathrm{Cp}_{2} \mathrm{Fe}^{0 /+}$ couple. Bridge centered, irreversible oxidations are observed at higher potentials, mostly as twoelectron waves. Upon increasing the sweep rate, the peak currents of the bridge-based oxidations decrease and approach the oneelectron limit but they remain chemically irreversible. The loss of the cathodic reverse peak(s) associated with the first two oxidations after scanning through the bridge oxidation and the distortion of successive voltammograms signals electrode filming. This required thorough wiping of the electrode after passing through the bridge-based oxidation.

It is also of interest to compare the half-wave potentials of derivatives 18/14 that only differ with respect to the $5^{\prime}$-substituent at the second thiophene ring ( $\mathrm{Br}$ for $\mathbf{1 8}$ but 2,5-dimethyl-1'-azaferrocenyl for 14). Compound 18 exhibits a reversible one-electron oxidation at $+0.190 \mathrm{~V}$ and an irreversible bridge oxidation at $0.85 \mathrm{~V}$. The half-wave potential of the $\mathbf{1 8 / 1 \mathbf { 8 } ^ { + }}$ couple is thus exactly midway between that of the two one-electron, azaferrocenyl based oxidations at +0.142 and $+0.242 \mathrm{~V}$ of $\mathbf{1 4}$. Reasons that could account for the cathodic shift of the first oxidation wave of $\mathbf{1 4}$ when compared to $\mathbf{1 8}$ are the lesser electron withdrawing effect of the 2,5-dimethyl-azaferrocenyl substituent with respect to the 
1044

12
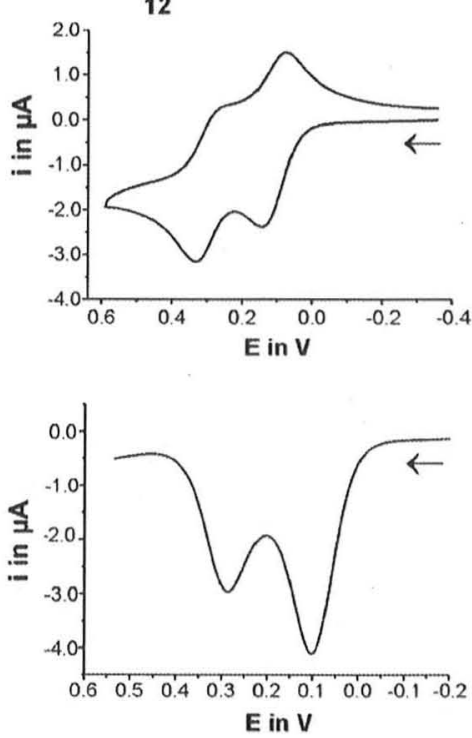
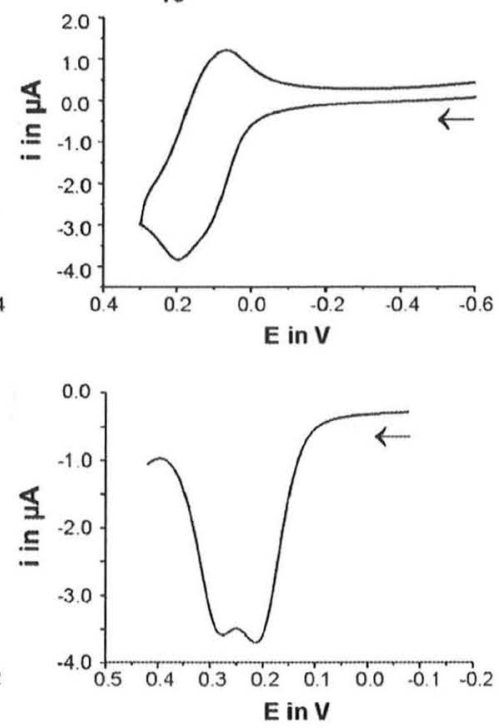

14
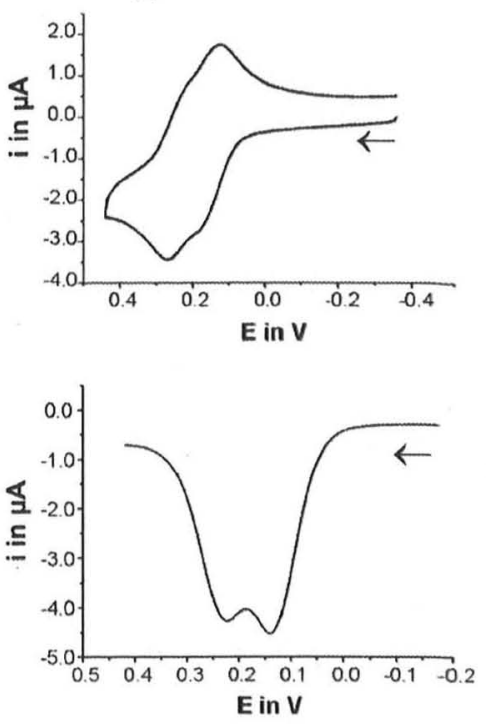

Fig. 4. Cyclic (upper row) and square wave voltammograms (lower row) of compounds 12 (left), 13 (middle) and 14 (right) in $\mathrm{CH}_{2} \mathrm{Cl}_{2} / \mathrm{NBu}_{4} \mathrm{PF}_{6}$ at $T=293 \mathrm{~K}$.

Table 1

Voltammetric data for compounds 12,13 and 14 , their bromo-substituted precursors 16,17 and 18 and of parent 2,5-dimethylazaferrocene 15

\begin{tabular}{llllll}
\hline Compound & $E_{1 / 2}{ }^{0 /+}[\mathrm{V}]$ & $E_{1 / 2}{ }^{+/ 2+}$ & $\Delta E_{1 / 2}[\mathrm{~V}]$ & $K_{\mathrm{c}}$ & $i_{\mathrm{p} . \text { bridge }}{ }^{a}$ \\
\hline $\mathbf{1 2}$ & $0.127( \pm 2)$ & $0.313( \pm 2)$ & $0.185( \pm 4)$ & $1540( \pm 240)$ & $0.85( \pm 5)$ \\
$\mathbf{1 3}$ & $0.193( \pm 3)$ & $0.273( \pm 3)$ & $0.080( \pm 6)$ & $24( \pm 5)$ & $0.92( \pm 5)$ \\
$\mathbf{1 4}$ & $0.142( \pm 3)$ & $0.242( \pm 2)$ & $0.100( \pm 3)$ & $55( \pm 5)$ & $0.73( \pm 5)$ \\
$\mathbf{1 8}^{\text {b }}$ & $0.190( \pm 2)$ & n. a. & n. a. & n. a. & $0.85( \pm 5)$ \\
$\mathbf{1 5}^{\text {b }}$ & $0.170( \pm 2)$ & n. a. & n. a. & n. a. & $1.02( \pm 5)$ \\
$\mathbf{1 6}^{\text {b }}$ & $0.215( \pm 2)$ & n. a. & n. a. & n. a. & $0.88( \pm 5)$ \\
$\mathbf{1 7}^{\text {b }}$ & $0.265( \pm 2)$ & n. a. & n. a. & n. a. & $1.03( \pm 5)$ \\
\hline
\end{tabular}

a Peak potential of an irreversible process at $293 \mathrm{~K}$ and $v=0.1 \mathrm{~V} / \mathrm{s}$.

b Data taken from Ref. [13].

bromide, a gain of thermodynamic stabilization for the mixed-valent radical cation $\mathbf{1 4}^{+}$by "electronic communication" which is not available for $\mathbf{1 8}^{+}$, or a mélange of both. Whichever the reason is, the cathodic shift of the $14 / 14^{+}$couple with respect to $18 / \mathbf{1 8}^{+}$signals conjugation between the bithiophene and the azaferrocenyl subunits of $\mathbf{1 4}$ and 18. An even larger shift is observed for 12/16 with a single thiophene ring as the intervening bridge. For pair 13/17 with the weakly conjugating 2,6-pyridinediyl bridge the shift is consequently smaller.

In order to directly probe for electronic interactions between the individual azaferrocenyl entities we attempted to record UVVis-NIR spectra of the intermediate radical cation of thiophenyl bridged $\mathbf{1 2}^{+}$with the largest comproportionation constant of this series. Repeated attempts to electrogenerate and characterize $\mathbf{1 2}^{+}$ inside our OTTLE cell were, however, not met by success and inevitably led to rapid filming of the working electrode. Obviously, oxidized 12 electropolymerizes rapidly. This is a well-known behavior of thiophenes [20-22].

The radical cation of parent $\mathbf{1 5}$, in contrast, could be unambiguously identified by this technique. Neutral $\mathbf{1 5}$ absorbs at 495 436 and $330 \mathrm{~nm}$. These bands relate to the ${ }^{1} \mathrm{~A}_{1 \mathrm{~g}} \rightarrow{ }^{1} \mathrm{E}_{1 \mathrm{~g}}(\mathrm{a})$, ${ }^{1} \mathrm{~A}_{1 \mathrm{~g}} \rightarrow{ }^{1} \mathrm{E}_{2 \mathrm{~g}}$ and ${ }^{1} \mathrm{~A}_{1 \mathrm{~g}} \rightarrow{ }^{1} \mathrm{E}_{1 \mathrm{~g}}$ (b) absorptions that are observed at 458,436 and $330 \mathrm{~nm}$ for parent ferrocene and at higher energies for methyl substituted derivatives [23]. Upon oxidation these bands red-shift to 735,697 and $570 \mathrm{~nm} . \mathbf{1 5}^{+}$thus absorbs at lower energy than poly-2,5-bis-(2-thiophene)-1', $2^{\prime}, 3^{\prime}, 4^{\prime}, 5^{\prime}$-pentamethylazaferrocene $\left(\lambda_{\max }=662 \mathrm{~nm}\right)$ [22] and parent ferrocenium (641 and $631 \mathrm{~nm})$, but at similar energy as the 1,1'-dimethylferrocenium ion $(711,702 \mathrm{~nm})[24]$. Even under the conditions of spectroelectrochemistry, $\mathbf{1 5}^{+}$is only short-lived and is subject to polymerization upon which the radical cation bands disappear while a red film forms on the working electrode. The extinction coefficients provided in Fig. 5 are therefore just a lower estimate. Attempts to record the ESR spectrum of electrogenerated $\mathbf{1 5}^{+}$, however, failed even when the electrolysis was performed at $-20^{\circ} \mathrm{C}$ and when the probe was cooled to $4 \mathrm{~K}$.

\subsection{X-Ray diffraction study of 2,5-dimethylazaferrocene (15)}

2,5-Dimethylazaferrocene (15) was first synthesized in 1964 by Pauson et al. [25]. Along with azaferrocene $\mathbf{2 0}$ (Fig. 6) it is the simplest heteroferrocene.

To the best of our knowledge, no X-ray crystal structures have been reported for either $\mathbf{1 5}$ or $\mathbf{2 0}$ up to now. 2,5-Dimethylazaferro-

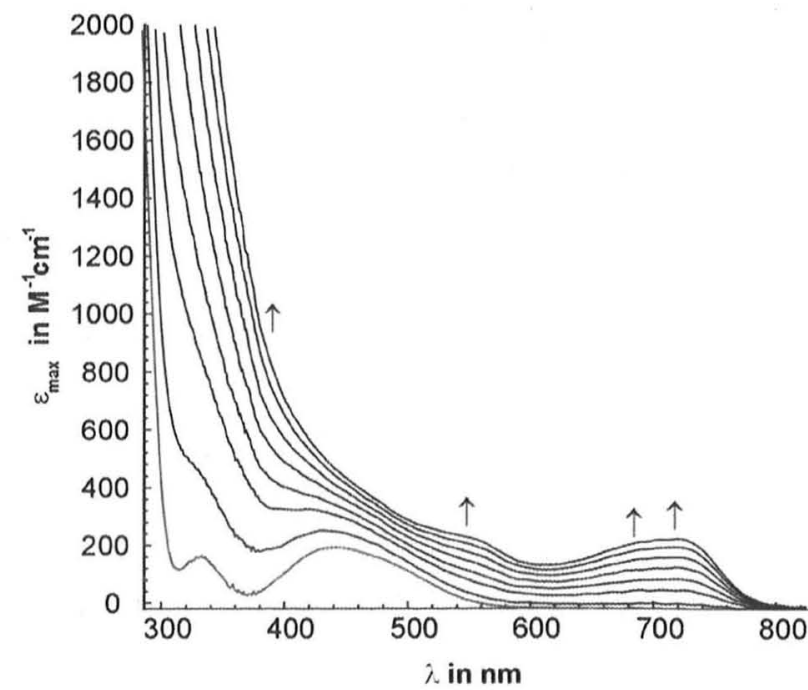

Fig. 5. UV-Vis-NIR spectroelectrochemistry on 2,5-dimethylazaferrocene in $\mathrm{C}_{4} \mathrm{H}_{4} \mathrm{Cl}_{2}-1,2 / \mathrm{NBu}_{4} \mathrm{PF}_{6}$ 


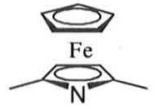

15

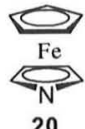

20
Fig. 6. The structures of 2,5-dimethylazaferrocene $\mathbf{1 5}$ and azaferrocene $\mathbf{2 0}$

cene (15) reportedly forms an oil at room temperature [25,26]. We now have found that after careful removal of residual solvent in a freeze/pump procedure $\mathbf{1 5}$ forms crystals which do not melt at room temperature for hours under vacuum. This initial observation led, after several attempts, to crystals suitable for X-ray diffraction analysis. It is, however, important to underline that selection of the best crystals and their manipulation were carried out at low temperatures. Compound $\mathbf{1 5}$ crystallizes in the orthorhombic space group Pbca. Data pertaining to the data collection and structure refinement are collected in Table 2 . Table 3 provides a selection of the most important interatomic distances and bond angles. A plot of an individual molecule of $\mathbf{1 5}$ is displayed in Fig. 7.

The iron atom is sandwiched between a $\pi$-bonded 2,5-dimethylpyrrole and a $\pi$-bonded cyclopentadienyl ring with distances of $1.652 \AA$ to the centroid of the pyrrole $\left(\mathrm{Pyr}_{\text {centr }}\right)$ and $1.657 \AA$ to the centroid of the cyclopentadienyl ring ( $\left.\mathrm{Cp}_{\text {centr }}\right)$. Interestingly the DFT/B3LYP calculations on azaferrocene $\mathbf{2 0}$ predict the reverse tendency with a longer distance of $1.659 \AA$ for $\mathrm{Fe}-\mathrm{Pyr}_{\text {centr }}$ and shorter one of $1.653 \AA$ for $\mathrm{Fe}-\mathrm{Cp}_{\text {centr }}$ [27]. The two Fe . . ring centroid vectors in 15 subtend an angle of $177.9^{\circ}$ at the iron atom. In the crystal 15 adopts a geometry intermediate between staggered and eclipsed. The average $\mathrm{C}(\mathrm{Cp})-\mathrm{Cp}_{\text {centr }}-\mathrm{Pyr}_{\text {centr }}-\mathrm{C} / \mathrm{N}(\mathrm{Pyr})$ angle is $17.9^{\circ}$. Each of the two rings in 15 is planar within $0.004 \AA$ and their planes are inclined toward each other by $2.9^{\circ}$. There remains the question whether this inclination reflects the known tendency of the pyrrole ligand to undergo a haptotropic $\eta^{5} \rightarrow \eta^{1}$ shift [28]. The distance between the perpendicular projection of the iron atom on the Pyr ring plane and the Pyr centroid is $0.024 \AA$ in $\mathbf{1 5}$. The analogous distance for the iron atom and the $C p$ ring is $0.016 \AA$.

In the solid state molecules of $\mathbf{1 5}$ are stabilized by weak interactions only and exhibit a hierarchic pattern of organization. At the simplest level, molecules of $\mathbf{1 5}$ form infinite layers along the

Table 2

Crystal data and structure refinement for $\mathbf{1 5}$

\begin{tabular}{ll}
\hline Compound & $\mathbf{1 5}$ \\
\hline Empirical formula & $\mathrm{C}_{11} \mathrm{H}_{13} \mathrm{FeN}$ \\
Formula weight & 215.07 \\
Temperature $(\mathrm{K})$ & $123(1)$ \\
Wavelength & $1.54184 \AA / \mathrm{Cu} \mathrm{K}_{\alpha}$ \\
Crystal system, space group & Orthorhombic, Pbca \\
Unit cell dimensions & \\
$a(\AA)$ & $12.3490(2)$ \\
$b(\AA)$ & $7.95460(10)$ \\
$c(\AA)$ & $19.1921(3)$ \\
Volume, $Z$ & $1885.27(5) \AA^{3}, 4$ \\
Density (calculated) $\left(\mathrm{mg} / \mathrm{m}^{3}\right)$ & 1.515 \\
Absorption coefficient $\left(\mathrm{mm}^{-1}\right)$ & 12.378 \\
$F(000)$ & 896 \\
Crystal color/morphology & Orange-brown stick \\
Crystal size (mm) & $0.47 \times 0.22 \times 0.16$ \\
$\theta$ range for data collection $\left({ }^{\circ}\right)$ & $5.84-66.68$ \\
Index ranges & $-14 \leqslant h \leqslant 14,-9 \leqslant k \leqslant 8,-22 \leqslant l \leqslant 22$ \\
Reflns collected/unique $\left[R_{\text {(int) }}\right]$ & $7170 / 1642[0.0428]$ \\
Reflns observed $[I>2 \sigma(I)]$ & 1343 \\
Absorption correction & Semi-empirical from equivalents \\
Data/restraints/parameters & $1642 / 0 / 118$ \\
Goodness-of-fit on $F^{2}$ & 1.102 \\
Final $R$ indices $[I>2 \sigma(I)]$ & $R_{1}=0.0406, w R_{2}=0.1175$ \\
$R$ indices (all data) & $R_{1}=0.0490, w R_{2}=0.1230$ \\
Largest difference peak, hole $\left(\mathrm{e} \AA^{3}\right)$ & $0.613,-0.555$ \\
\hline &
\end{tabular}

Table 3

Selected bond lengths $(A)$ and bond angles $\left(^{\circ}\right)$ for compound 15

\begin{tabular}{ll}
\hline $\mathbf{1 5}$ & \\
\hline $\mathrm{Fe}(1)-\mathrm{N}(1)$ & $2.032(2)$ \\
$\mathrm{Fe}(1)-\mathrm{C}(1)$ & $2.024(3)$ \\
$\mathrm{Fe}(1)-\mathrm{C}(2)$ & $2.020(3)$ \\
$\mathrm{Fe}(1)-\mathrm{C}(3)$ & $2.057(3)$ \\
$\mathrm{Fe}(1)-\mathrm{C}(4)$ & $2.064(4)$ \\
$\mathrm{Fe}(1)-\mathrm{C}(7)$ & $2.053(4)$ \\
$\mathrm{Fe}(1)-\mathrm{C}(8)$ & $2.060(3)$ \\
$\mathrm{Fe}(1)-\mathrm{C}(9)$ & $2.048(3)$ \\
$\mathrm{Fe}(1)-\mathrm{C}(10)$ & $2.043(3)$ \\
$\mathrm{Fe}(1)-\mathrm{C}(11)$ & $2.047(3)$ \\
$\mathrm{N}(1)-\mathrm{C}(1)$ & $1.394(4)$ \\
$\mathrm{N}(1)-\mathrm{C}(2)$ & $1.381(4)$ \\
$\mathrm{C}(1)-\mathrm{C}(4)$ & $1.426(5)$ \\
$\mathrm{C}(2)-\mathrm{C}(3)$ & $1.417(4)$ \\
$\mathrm{C}(3)-\mathrm{C}(4)$ & $1.410(5)$ \\
$\mathrm{C}(2)-\mathrm{C}(6)$ & $1.502(5)$ \\
$\mathrm{C}(7)-\mathrm{C}(8)$ & $1.426(5)$ \\
$\mathrm{C}(8)-\mathrm{C}(9)$ & $1.413(4)$ \\
$\mathrm{C}(9)-\mathrm{C}(10)$ & $1.417(4)$ \\
$\mathrm{C}(10)-\mathrm{C}(11)$ & $1.422(4)$ \\
$\mathrm{C}(7)-\mathrm{C}(11)$ & $1.417(5)$ \\
$\mathrm{C}(1)-\mathrm{N}(1)-\mathrm{C}(2)$ & $106.3(2)$ \\
$\mathrm{C}(2)-\mathrm{C}(3)-\mathrm{C}(4)$ & $106.8(3)$ \\
$\mathrm{C}(4)-\mathrm{C}(1)-\mathrm{C}(5)$ & $127.6(3)$ \\
$\mathrm{C}(9)-\mathrm{C}(10)-\mathrm{C}(11)$ & $107.9(3)$ \\
$\mathrm{C}(7)-\mathrm{C}(8)-\mathrm{C}(9)$ & $107.4(3)$ \\
& \\
&
\end{tabular}

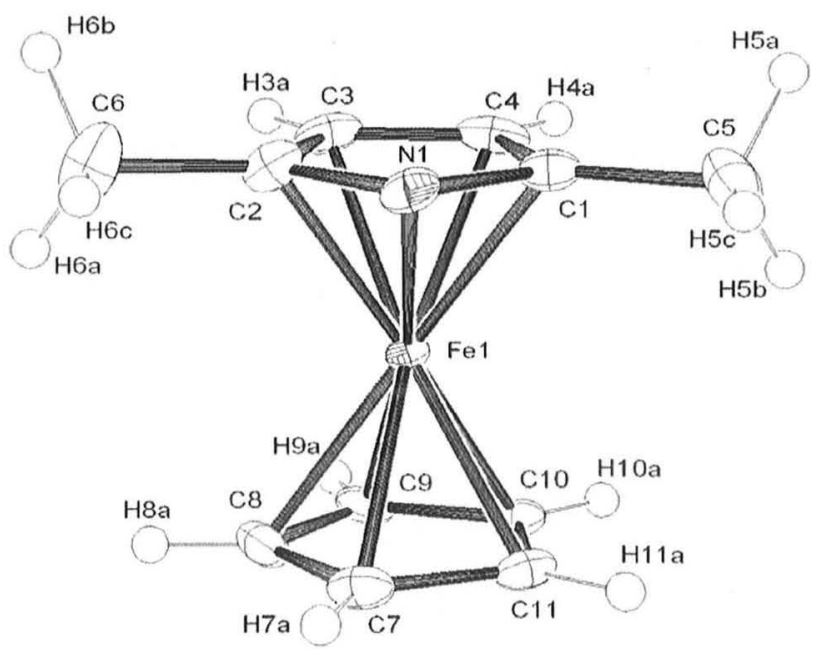

Fig. 7. ORTEP plot of the molecular structure of complex $\mathbf{1 5}$ in the crystal. Ellipsoids are drawn on a $50 \%$ probability level.

crystallographic ac plane. The layers are stabilized by intermolecular $\mathrm{CH}$... c contacts of $2.763 \AA$ between cyclopentadienyl proton $\mathrm{H}(8 \mathrm{~A})$ and carbon atom $\mathrm{C}(10)$ of the partner molecules' cyclopentadienyl ring. Additional stabilization is generated by intermolecular $\mathrm{H}$. . H contacts of $2.204 \AA$ between methyl group proton $\mathrm{H}(6 \mathrm{~B})$ and methyl group proton $\mathrm{H}(5 \mathrm{~B})$. Within each layer the pyrrol nitrogen $\mathrm{N}(1)$ and carbon $\mathrm{C}(2)$ atoms both form weak (2.583 $\AA$ and $2.630 \AA \AA)$ intermolecular contacts with the same methyl group proton $H(5 A)$. The layers are held together by $\mathrm{H} \cdots \mathrm{H}$ intermolecular contacts of $2.315 \AA$ between methyl group proton $\mathrm{H}(6 \mathrm{C})$ and methyl group proton $\mathrm{H}(5 \mathrm{C})$ from the second parallel layer. The bilayers that are generated in this manner are again held together by weak $\mathrm{H} \ldots \mathrm{H}$ contacts with the strongest such interaction between cyclopentadienyl proton $\mathrm{H}(9 \mathrm{~A})$ and methyl group proton $\mathrm{H}(6 \mathrm{~B})$ with a distance of $2.514 \AA$. One can assume that this relatively weak bilayer stabilization accounts for the oily character of $\mathbf{1 5}$ at room 


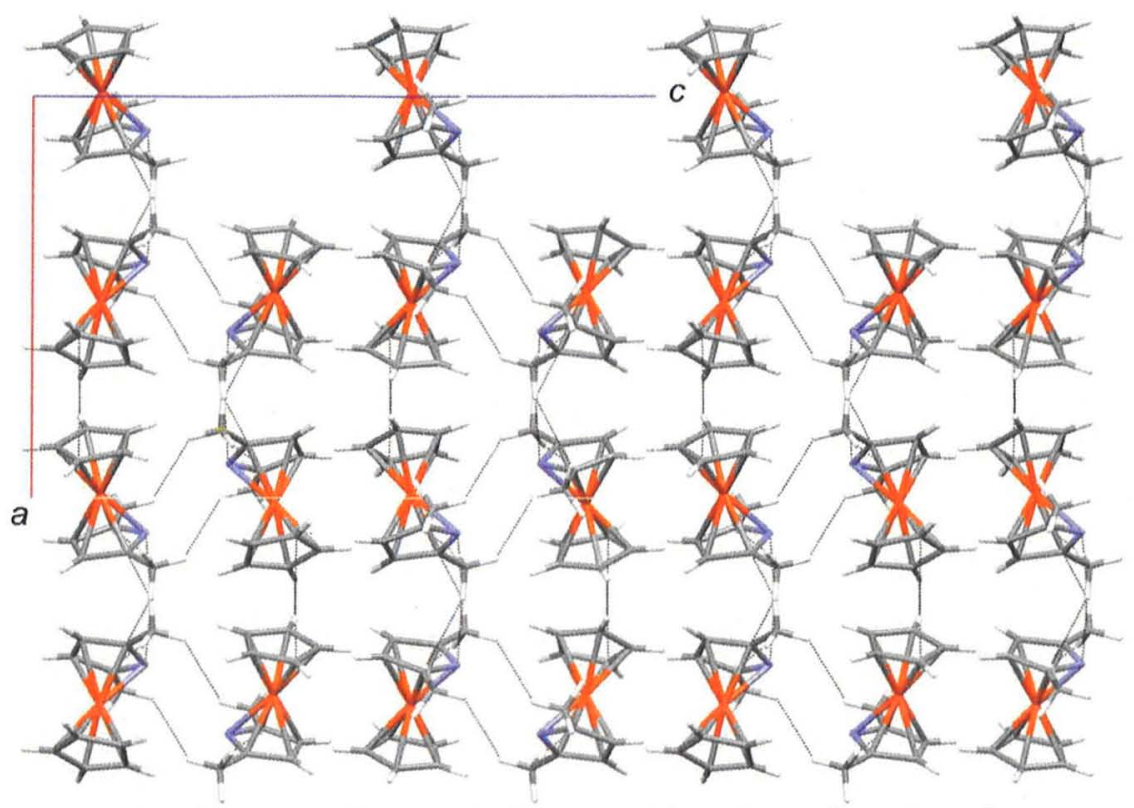

$\leftarrow 2.315 \AA \rightarrow \leftarrow 2.514 \AA \rightarrow \leftarrow 2.315 \AA \rightarrow \leftarrow 2.514 \AA \rightarrow \leftarrow 2.315 \AA \rightarrow \leftarrow 2.514 \AA \rightarrow$

Fig. 8. Perpendicular projection of layers formed by molecules of $\mathbf{1 5}$ on the crystallographic ac plane. Weak intermolecular contacts within bilayers are marked by dashed lines.

temperature. The perpendicular projection of layers on crystallographic ac plane is shown in Fig. 8.

\section{Conclusions}

Dinuclear 2,5-dimethylazaferrocene derivatives 12,14 and 13 having heteroaryl (thiophenyl, bithiophenyl, pyridyl) bridges have been readily prepared by palladium catalyzed cross-coupling reactions of 2,5-dimethylazaferrocenezinc chloride with the respective bromo-substituted heteroarene precursor. Electrochemical studies reveal that each of these complexes undergoes two consecutive one-electron oxidations to the modestly stable respective dications. The thermodynamic stabilities of the intermediate mixedvalent radical cations increase in the order 2,6-pyridyl bridged $\mathbf{1 3}<5,5^{\prime}$-bithiophenyl bridged $\mathbf{1 4}<2,5$-thiophenyl bridged $\mathbf{1 2}$ and follow the expected trend. The $K_{\mathrm{c}}$ values of the radical cations are notably larger than for analogous ferrocenes, possibly as a result of the lower energy gap between the end-group and bridgebased oxidations. Parent 2,5-dimethylazaferrocene was also investigated by $\mathrm{X}$-ray crystallography and exhibits a close to symmetrical binding of the iron to the two different rings. Weak intermolecular forces between individual molecules of $\mathbf{1 5}$ explain its oily character and previous failures to obtain crystals of this molecule. The associated azaferrocenium ion $\mathbf{1 5}^{+}$proved to be sufficiently stable to be characterized by optical spectroscopy. Bands are shifted to lower energy when compared to the ferrocenium ion but are at similar energy as in 1,1'-dimethylferrocenium salts.

\section{Experimental}

\subsection{General remarks}

All preparations were carried out using standard Schlenk techniques. Chromatographic separations were carried out using silica gel 60 (Merck, 230-400 mesh ASTM). Tetrahydrofuran was distilled over sodium benzophenone ketyl. Other solvents were of reagent grade and were used without prior purification. 2,5-
Dimethylazaferrocene was prepared according to the literature procedure [26]. All other chemicals were purchased from Aldrich Chemical Co. NMR spectra were recorded on a Bruker AV300 spectrometer. Chemical shifts are reported in $\delta(\mathrm{ppm})$ using residual $\mathrm{CHCl}_{3}\left({ }^{1} \mathrm{H} \delta 7.26 \mathrm{ppm}\right)$ and $\mathrm{CDHCl}_{2}\left({ }^{1} \mathrm{H} \delta 5.32 \mathrm{ppm}\right)$ as the reference. Mass spectra were recorded using El methods on a Finnigan MAT 710A spectrometer. Microanalyses were determined by Analytical Services of the University of Regensburg.

Electrochemical work was performed on a BAS CV50 potentiostat in a home-built vacuum tight one-compartment cell using Pt or glassy carbon disk electrodes from BAS as the working electrode, a platinum spiral as the counter electrode and a silver spiral as a pseudo-reference electrode. Each of the spiral-shaped electrodes is welded to Vycon wire and sealed into a glass tube. Counter and reference electrodes are introduced into the cell by appropriate fittings in the side-wall and sealed via a Quickfit screw. $\mathrm{CH}_{2} \mathrm{Cl}_{2}$ for electrochemical use was of Burdick\&Jackson brand (Fluka) and was distilled from $\mathrm{CaH}_{2}$, deoxygenated by saturation with argon and briefly stored over molecular sieves. Potential calibration was performed by adding ferrocene or decamethylferrocene $\left(E_{1 / 2}=-0.545 \mathrm{~V}\right.$ versus $\left.\mathrm{Cp}_{2} \mathrm{Fe}^{0 /+}\right)$ as an internal standard to the analyte solution. The amount of the reference system was adjusted until the peak currents of the respective standard were comparable to those of the analyte. Potentials are given against the ferrocene/ferrocenium couple. The splittings of half-wave potentials were directly taken from the CVs, square wave and differential pulse voltammograms (12) or by deconvolution of the overlapping peaks in square wave and differential pulse voltammetry $(\mathbf{1 3}, \mathbf{1 4}) . \Delta E_{1 / 2}$ values were independently calculated from the $\mathrm{CV}$ peak potential separations and forward wave half-widths by the method of Richardson and Taube [11]. Values obtained from different methods were identical within $\pm 6 \mathrm{mV}$.

\subsubsection{Synthesis of $1^{\prime}-\left(5-\left(5^{\prime}\right.\right.$-bromo-2,2'-bithiophenyl $\left.)\right)-2,5-$ dimethylazaferrocene (18)}

Sec-BuLi (1.4 M in cyclohexane, $1.3 \mathrm{ml}, 1.8 \mathrm{mmol})$ was added to an argon-saturated THF $(12 \mathrm{ml})$ solution of 2,5-dimethylazaferro- 
cene (263 mg, $1.22 \mathrm{mmol}$ ) and TMEDA (95 $\mu \mathrm{l}, 0.06 \mathrm{mmol}$ ) at $-78^{\circ} \mathrm{C}$. After the mixture was stirred for $1.5 \mathrm{~h}$ at $-78^{\circ} \mathrm{C}, \mathrm{ZnCl}_{2}$ (240 $\mathrm{mg}, 1.76 \mathrm{mmol}$ ) was added and the reacting mixture was warmed to room temperature and stirred for $1.5 \mathrm{~h}$. Then, to the reacting mixture a suspension of $\mathrm{PdCl}_{2}\left(\mathrm{PPh}_{3}\right)_{2}(42 \mathrm{mg}, 0.06 \mathrm{mmol})$ in THF $(2 \mathrm{ml})$ and a solution of $5,5^{\prime}$-dibromo-2,2'-bithiophene (454 mg, $1.40 \mathrm{mmol})$ in THF ( $3 \mathrm{ml}$ ) were added. The reaction mixture was stirred at room temperature for $2 \mathrm{~h}$ and then poured onto water. After workup, compound $\mathbf{1 8}$ was purified by column chromatography on silica gel by eluting with ethyl acetate and crystallized from $n$-hexane. Yield: $250 \mathrm{mg}(45 \%)$.

${ }^{1} \mathrm{H}$ NMR $\left(300 \mathrm{MHz}, \mathrm{CDCl}_{3}\right): \delta 6.97\left(\mathrm{~d}, 3 \mathrm{H},{ }^{3} \mathrm{JHH}_{\mathrm{HH}}=3.6 \mathrm{~Hz}\right.$, H thienyl), $6.90\left(\mathrm{~d}, 1 \mathrm{H},{ }^{3} J_{\mathrm{HH}}=3.8 \mathrm{~Hz}, \mathrm{H}\right.$ thienyl), $4.50(\mathrm{~s}, 2 \mathrm{H}, \mathrm{Cp}), 4.33(\mathrm{~s}$, $2 \mathrm{H}, \mathrm{Cp}), 4.29$ (s, $2 \mathrm{H}, \beta$-pyrrolyl), $2.11\left(\mathrm{~s}, 6 \mathrm{H}, \mathrm{CH}_{3}\right.$ ) HRMS (EI, $70 \mathrm{eV}$ ): 456.9261 (Calc. for $\mathrm{C}_{19} \mathrm{H}_{16} \mathrm{BrFeNS}_{2}: 456.9257$ ). Anal. Calc. for $\mathrm{C}_{19} \mathrm{H}_{16} \mathrm{BrFeNS}_{2}$ : $\mathrm{C}, 49.90 ; \mathrm{H}, 3.53 ; \mathrm{N}, 3.06 ; \mathrm{S}, 13.99$. Found: $\mathrm{C}$, $50.35 ; \mathrm{H}, 3.69 ; \mathrm{N}, 2.96 ; \mathrm{S}, 13.88 \%$.

\subsubsection{Synthesis of 2,5-di(1'-(2,5-dimethylazaferrocenyl))thiophene (12)}

Sec-BuLi (1.4 M in cyclohexane, $0.8 \mathrm{ml}, 1.12 \mathrm{mmol}$ ) was added to an argon-saturated THF (12 ml) solution of 2,5-dimethylazaferrocene $(158 \mathrm{mg}, 0.73 \mathrm{mmol})$ and TMEDA $(70 \mu \mathrm{l})$ at $-78{ }^{\circ} \mathrm{C}$. After the mixture was stirred for $1.5 \mathrm{~h}$ at $-78^{\circ} \mathrm{C}, \mathrm{ZnCl}_{2}$ ( $148 \mathrm{mg}$, $1.08 \mathrm{mmol}$ ) was added and the reacting mixture was warmed to room temperature and stirred for $1.5 \mathrm{~h}$. Then, a suspension of $\mathrm{PdCl}_{2}\left(\mathrm{PPh}_{3}\right)_{2}(26 \mathrm{mg}, 0.04 \mathrm{mmol})$ in $\mathrm{THF}(1.5 \mathrm{ml})$ and a solution of 1'-(2-bromothiophen-5-yl)-2,5-dimethylazaferrocene (16) (70 $\mathrm{mg}, 0.18 \mathrm{mmol})$ in THF $(2 \mathrm{ml})$ were added. The reaction mixture was stirred at room temperature for $2 \mathrm{~h}$ and then poured onto water. After workup, complex 12 was purified by column chromatography on silica gel by eluting with ethyl acetate-methanol (50:2) mixture and crystallized from $n$-hexane. Yield: $53 \mathrm{mg}$ (58\%).

${ }^{1} \mathrm{H}$ NMR $\left(300 \mathrm{MHz}, \mathrm{CDCl}_{3}\right): \delta 6.96(\mathrm{~s}, 2 \mathrm{H}, \mathrm{H}$ thienyl), $4.50(\mathrm{~s}, 4 \mathrm{H}$, Cp), 4.31 (s, 4H, Cp), 4.27 (s, 4H, $\beta$-pyrrolyl), 2.12 (s, 12H, $\mathrm{CH}_{3}$ ). MS (EI, 70eV): $\mathrm{m} / \mathrm{z} 510.0\left(\mathrm{M}^{+}\right), 416.0\left(\mathrm{M}^{+}-\mathrm{C}_{6} \mathrm{H}_{8} \mathrm{~N}\right), 94.0\left(\mathrm{C}_{6} \mathrm{H}_{8} \mathrm{~N}\right)$. HRMS: $m / z 510.0513$ (Calc. for $\mathrm{C}_{26} \mathrm{H}_{26} \mathrm{Fe}_{2} \mathrm{~N}_{2} \mathrm{~S}: 510.0515$ ). Anal. Calc. for $\mathrm{C}_{26} \mathrm{H}_{26} \mathrm{Fe}_{2} \mathrm{~N}_{2} \mathrm{~S}$ : C, 61.17; $\mathrm{H}, 5.14 ; \mathrm{N}, 5.49 ; \mathrm{S}, 6.27$. Found: $\mathrm{C}$, $60.83 ; \mathrm{H}, 5.38 ; \mathrm{N}, 5.32 ; \mathrm{S}, 6.03 \%$.

$1^{\prime}$-(thien-2-yl)-2,5-dimethylazaferrocene (19): ${ }^{1} \mathrm{H}$ NMR (300 MHz, $\left.\mathrm{CDCl}_{3}\right): \delta 7.18\left(\mathrm{~d}, 1 \mathrm{H},{ }^{3} J_{\mathrm{HH}}=4.7 \mathrm{~Hz}, \mathrm{H}\right.$ thienyl), $7.08(\mathrm{~d}, 1 \mathrm{H}$, ${ }^{3} J_{\mathrm{HH}}=2.8 \mathrm{~Hz}, \mathrm{H}$ thienyl), $6.97\left(\mathrm{dd}, 1 \mathrm{H},{ }^{3} J_{\mathrm{HH}}=4.7 \mathrm{~Hz},{ }^{3} J_{\mathrm{HH}}=2.8 \mathrm{~Hz}\right.$, $\mathrm{H}$ thienyl), 4.50 (s, 2H, Cp), 4.29 (s, 2H, Cp), 4.24 (s, 2H, $\beta$-pyrrolyl), $2.07\left(\mathrm{~s}, 6 \mathrm{H}, \mathrm{CH}_{3}\right)$. MS (EI, 70eV): $\mathrm{m} / \mathrm{z} 296.9\left(\mathrm{M}^{+}\right)$.

4.1.3. Synthesis of 2,6-di(1'-(2,5-dimethylazaferrocenyl))pyridine (13) The synthesis was performed as in Section 4.1.2., but with 1'-(2bromopyridin-6-yl)-2,5-dimethylazaferrocene (17) (60 mg, $0.16 \mathrm{mmol}$ ). Yield: $49 \mathrm{mg}(61 \%)$.

${ }^{1} \mathrm{H}$ NMR $\left(300 \mathrm{MHz}, \mathrm{CD}_{2} \mathrm{Cl}_{2}\right): \delta 7.59\left(\mathrm{t}, 1 \mathrm{H},{ }^{3} \mathrm{JHH}_{\mathrm{HH}}=7.7 \mathrm{~Hz}, \mathrm{H}\right.$ pyridinyl), $7.30\left(\mathrm{~d}, 2 \mathrm{H},{ }^{3} \mathrm{JHH}_{\mathrm{H}}=7.7 \mathrm{~Hz}, \mathrm{H}\right.$ pyridinyl), 4.93 (pseudo-t, $4 \mathrm{H}$, $J=1.6 \mathrm{~Hz}, \mathrm{Cp}$ ), 4.40 (pseudo-t, $4 \mathrm{H}, J=1.6 \mathrm{~Hz}, \mathrm{Cp}), 4.24(\mathrm{~s}, 4 \mathrm{H}, \beta-$ pyrrolyl), $2.03\left(\mathrm{~s}, 12 \mathrm{H}, \mathrm{CH}_{3}\right) .{ }^{1} \mathrm{H}$ NMR $\left(300 \mathrm{MHz}, \mathrm{CDCl}_{3}\right): \delta 7.56(\mathrm{t}$, $1 \mathrm{H},{ }^{3} \mathrm{~J}_{\mathrm{HH}}=7.7 \mathrm{~Hz}, \mathrm{H}$ pyridinyl), 7.29 (d, $1 \mathrm{H}$ shielded by solvent signal, $\mathrm{H}$ pyridinyl), 4.95 (s, 4H, Cp), $4.41(\mathrm{~s}, 4 \mathrm{H}, \mathrm{Cp}), 4.23(\mathrm{~s}, 4 \mathrm{H}, \beta-$ pyrrolyl), $2.06\left(\mathrm{~s}, 12 \mathrm{H}, \mathrm{CH}_{3}\right)$. MS (EI, 70eV): $\mathrm{m} / z 505.0\left(\mathrm{M}^{+}\right), 411.0$ $\left(\mathrm{M}^{+}-\mathrm{C}_{6} \mathrm{H}_{8} \mathrm{~N}\right), 94.0\left(\mathrm{C}_{6} \mathrm{H}_{8} \mathrm{~N}\right)$. HRMS: $\mathrm{m} / \mathrm{z} 505.0895$ (Calc. for $\mathrm{C}_{27} \mathrm{H}_{27} \mathrm{Fe}_{2} \mathrm{~N}_{3}$ : 505.0904). Anal. Calc. for $\mathrm{C}_{27} \mathrm{H}_{27} \mathrm{Fe}_{2} \mathrm{~N}_{3} \times 2 \mathrm{H}_{2} \mathrm{O}$ : C, $59.88 ; \mathrm{H}, 5.77 ; \mathrm{N}, 7.76$. Found: $\mathrm{C}, 59.20 ; \mathrm{H}, 5.33 ; \mathrm{N}, 7.49 \%$.

\subsubsection{Synthesis of 5,5'-di(1'-(2,5-dimethylazaferrocenyl))-2,2'-} bithiophene (14)

The synthesis was performed as in Section 4.1.2. but with 1'-(5(5'-bromo-2,2'-bithiophenyl))-2,5-dimethylazaferrocene (18) (60 mg, $0.13 \mathrm{mmol})$. Yield: $56 \mathrm{mg}(73 \%)$.
${ }^{1} \mathrm{H}$ NMR $\left(300 \mathrm{MHz}, \mathrm{CDCl}_{3}\right): \delta 7.03\left(\mathrm{~d}, 2 \mathrm{H},{ }^{3} \mathrm{~J}_{\mathrm{HH}}=3.5 \mathrm{~Hz}, \mathrm{H}\right.$ thienyl), $6.99\left(\mathrm{~d}, 2 \mathrm{H},{ }^{3} \mathrm{~J}_{\mathrm{HH}}=3.5 \mathrm{~Hz}, \mathrm{H}\right.$ thienyl), $4.51(\mathrm{~s}, 4 \mathrm{H}, \mathrm{Cp}), 4.33$ (s, 4H, Cp), 4.29 (s, 4H, $\beta$-pyrrolyl), 2.14 (s, 12H, $\mathrm{CH}_{3}$ ). MS (EI, $70 \mathrm{eV}): \mathrm{m} / \mathrm{z} 591.7\left(\mathrm{M}^{+}\right), 295.9\left(\mathrm{M}^{+}-\mathrm{C}_{15} \mathrm{H}_{14} \mathrm{NSFe}\right)$. HRMS: $\mathrm{m} /$ $z=592.0387$ (Calc. for $\mathrm{C}_{30} \mathrm{H}_{28} \mathrm{Fe}_{2} \mathrm{~N}_{2} \mathrm{~S}_{2}: 592.0393$ ). Anal. Calc. for $\mathrm{C}_{30} \mathrm{H}_{28} \mathrm{Fe}_{2} \mathrm{~N}_{2} \mathrm{~S}_{2}$ : C, 60.81; $\mathrm{H}, 4.77 ; \mathrm{N}, 4.73 ; \mathrm{S}, 10.80$. Found: $\mathrm{C}$ $60.79 ; \mathrm{H}, 4.92 ; \mathrm{N}, 4.36 ; \mathrm{S}, 10.74 \%$.

\section{Crystal structure determination}

Diffraction data for crystals of compound $\mathbf{1 5}$ was collected with an Oxford Diffraction Gemini Ultra CCD diffractometer [29] with multilayer optics and $\mathrm{Cu} \mathrm{K} \alpha$ radiation $(\lambda=1.5418 \AA$ ). The structures were solved by direct methods (SIR-97) [30] and refined by full-matrix least-squares on $F^{2}$ (sHeLxL-97) [31]. H atoms were calculated geometrically and a riding model was applied during the refinement process. Packing diagrams were generated with the MERCURY program [32].

\section{Acknowledgment}

Dr. Konrad Kowalski is grateful to the Alexander von HumboldtStiftung for a research fellowship at the group of Prof. Dr. R.F. Winter, University of Regensburg.

\section{Appendix A. Supplementary material}

CCDC 690769 contains the supplementary crystallographic data for this paper. These data can be obtained free of charge from The Cambridge Crystallographic Data Centre via www.ccdc.cam.ac.uk/ data_request/cif. Supplementary data associated with this article can be found, in the online version, at doi:10.1016/j.jorganchem. 2008.09.003.

\section{References}

[1] (a) F. Paul, C. Lapinte, Coord. Chem. Rev. 178-180 (1998) 431

(b) P.F.H. Schwab, M.D. Levin, J. Michl, Chem. Rev. 99 (1999) 863

(c) N. Wheatley, P. Kalck, Chem. Rev. 99 (1999) 3379;

(d) V. Balzani, A. Juris, M. Venturi, S. Campagna, S. Serroni, Chem. Rev, 96 (1996) 759;

(e) A. Ceccon, S. Santi, L. Orian, A. Bisello, Coord. Chem. Rev. 248 (2004) 683;

(f) I.M. Bruce, J.P. Low, Adv. Organomet. Chem. 50 (2004) 179;

(g) S. Szafert, J.A. Gladysz, Chem. Soc. Rev. 103 (2003) 4175;

(h) M.D. Ward, Chem. Soc. Rev. (1995) 121.

[2] (a) S. Barlow, D. O'Hare, Chem. Rev. 97 (1997) 637;

(b) V. Grosshenny, A. Harriman, M. Hissler, R. Ziessel, Platinum Met. Rev, 40 (1996) 26;

(c) I.M. Bruce, Coord. Chem. Rev. 166 (1997) 91;

(d) M. Ratner, J. Jortner, Molecular Electronics, Blackwell Science, Malden, MA, 1997:

(e) M.J. Tour, Acc. Chem. Res. 33 (2000) 791:

(f) P.C. Collier, W.E. Wong, M. Belohradsky, M.F. Raymo, F.J. Stoddart, J.P. Kuekes, S.R. Williams, R. Heath, Science 285 (1999) 391;

(g) R.L. Carroll, Ch.B. Gorman, Angew. Chem., Int. Ed. 41 (2002) 4378;

(g) R.L. Carroll, Ch.B. Gorman, Angew. Chem., Int. Ed. 41 (2002)
(h) N. Robertson, C.A. McGowan, Chem. Soc. Rev. 32 (2003) 96.

[3] (a) C. Levada, K. Bechgaard, D.O. Cowan, J. Org. Chem. 16 (1976) 2700

(b) M.J. Powers, T.J. Meyer, J. Am. Chem. Soc. 100 (1978) 4393;

(c) A.C. Ribou, J.P. Launay, M.L. Sachtleben, H. Li, Ch.W. Spangler, Inorg. Chem. 35 (1996) 3735

(d) R.D. Adams, B. Qu, Organometallics 19 (2000) 2411

(e) R.D. Adams, B. Qu, M.D. Smith, Organometallics 21 (2002) 3867;

(f) A. Hradsky, B. Bildstein, N. Schuler, H. Schottenberger, P. Jaitner, K.H Ongania, K. Wurst, J.P. Launay, Organometallics 16 (1997) 392;

(g) S.P. Dudek, H.D. Sikes, Ch.E.D. Chidsey, J. Am. Chem. Soc. 123 (2001) 8033 (h) M.U. Winters, E. Dahlstedt, H.E. Blades, C.J. Wilson, M.J. Frampton, H.L. Anderson, B. Albinsson, J. Am. Chem. Soc. 129 (2007) 4291:

(i) S. Creager, C.J. Yu, C. Bamdad, S. O'Connor, T. MacLean, E. Lam, Y. Chong, G.T. Olsen, J. Luo, M. Gozin, J.F. Kayyem, J. Am. Chem. Soc. 121 (1999) 1059; (j) Ch. Engtrakul, L.R. Sita, Nano Lett. 10 (2001) 541;

(k) H. Fink, N.J. Long, A.J. Martin, G. Opromolla, A.J.P. White, D. Williams, P. Zanello, Oragnometallics 16 (1997) 2646:

(1) N. Szesni, M. Drexler, J. Maurer, R.F. Winter, F. de Montigny, C. Lapinte, S Steffens, J. Heck, B. Weibert, H. Fischer, Organometallics 25 (2006) 5774. 
[4] M. Iyoda, T. Kondo, T. Okabe, H. Matsuyama, S. Sasaki, Y. Kuwatani, Chem. Lett. (1997) 35.

[5] S. Ogawa, H. Muraoka, K. Kikuta, F. Saito, R. Sato, J. Organomet. Chem. 692 (2007) 60.

[6] M-A. Sato, K. Fukui, Synth. Met. 157 (2007) 619.

[7] M. Iyoda, T. Takano, N. Otani, K. Ugawa, M. Yoshida, H. Matsuyama, Y. Kuwatani, Chem. Lett. (2001) 1310.

[8] A. Caballero, V. Lloveras, D. Curiel, A. Tárraga, A. Espinosa, R. Garcia, J. VidalGancedo, C. Rovira, K. Wurst, P. Molina, J. Veciana, Inorg. Chem. 46 (2007) 825.

[9] A. Tárraga, P. Molina, D. Curiel, M.D. Velasco, Tetrahedron Lett. 43 (2002) 8453.

[10] A. Tárraga, P. Molina, D. Curiel, M.D. Velasco, Organometallics 20 (2001) 2145.

[11] D.E. Richardson, H. Taube, Inorg. Chem. 20 (1981) 1278.

[12] P. Mathur, A.K. Singh, V.K. Singh, P. Singh, R. Rahul, S.M. Mobin, C. Thöne, Organometallics 24 (2005) 4793

[13] K. Kowalski, R.F. Winter, J. Organomet. Chem. 693 (2008) 2181.

[14] K. Kowalski, J. Zakrzewski, J. Organomet. Chem. 689 (2004) 1046.

[15] P. Audebert, F. Miomandre, J. Zakrzewski, J. Electroanal. Chem. 530 (2002) 63.

[16] B. Brunschwig, C. Creutz, N. Sutin, Chem. Soc. Rev. 31 (2002) 168.

[17] K.Y. Wong, P.N. Schatz, Prog. Inorg. Chem. 28 (1981) 369.

[18] (a) M.E. Stoll, S.R. Lovelace, W.E. Geiger, H. Schimanke, I. Hyla-Kryspin, R. Gleiter, J. Am. Chem. Soc. 121 (1999) 9343;

(b) C.G. Atwood, W.E. Geiger, J. Am. Chem. Soc. 122 (2000) 5477:

(c) M. Bühl, W. Thiel, Inorg. Chem, 43 (2004) 6377;

(d) C. Lambert, G. Nöll, J. Am. Chem. Soc. 121 (1999) 8434;

(e) T. Ito, T. Hamaguchi, H. Nagino, T. Yamaguchi, H. Kido, I.S. Zavarine, T. Richmond, J. Washington, C.P. Kubiak, J. Am. Chem. Soc. 121 (1999) 4625

(f) S.V. Lindemann, S.V. Rosokha, J.K. Kochi, J. Am. Chem. Soc. 124 (2002) 843;

(g) P.H. Dinolfo, J.T. Hupp, J. Am. Chem. Soc, 126 (2004) 16814.
[19] (a) S. Santi, L. Orian, C. Durante, E.Z. Bencze, A. Bisello, A. Donoli, A. Ceccon, F, Benetello, L. Crociani, Chem. Eur. J. 13 (2007) 7933

(b) S. Patra, B. Sarkar, S. Ghumaan, J. Fiedler, W. Kaim, G.K. Lahiri, Inorg. Chem. (2004) 6108;

(c) S. Patra, B. Sarkar, S. Ghumaan, J. Fiedler, W. Kaim, G.K. Lahiri, Dalton Trans. (2004) 754

[20] G. Engelmann, W. Jugelt, G. Kossmehl, H-P. Welzel, P. Tschunky, J. Heinze, Macromolecules 29 (1996) 3370

[21] K. Meerholz, J. Heinze, Electrochim. Acta (1996) 1839.

[22] P.D. Byrne, P. Müller, T.M. Swager, Langmuir 22 (2006) 10596

[23] J.L. Robbins, N. Edelstein, B. Spencer, J.C. Smart, J. Am. Chem. Soc. 104 (1982) 1882.

[24] D.E.M. Duggan, D.N. Hendrickson, Inorg. Chem. 14 (1975) 955.

[25] K.K. Joshi, P.L. Pauson, A.R. Qazi, W.H. Stubbs, J. Organomet. Chem. 1 (1964) 471.

[26] J. Zakrzewski, Inorg. Chim. Acta 278 (1998) 101

[27] G. Frison, F. Mathey, A. Sevin, J. Phys. Chem. 106 (2002) 5653.

[28] D.P. Heenan, C. Long, V. Montiel-Palma, R.N. Perutz, M.T. Pryce, Organometallics 19 (2000) 3867

[29] CrysAlis CCD, Oxford Diffraction Ltd., Version 1.171.32.5 (release 08-05-2007 CrysAlis171,NET)

[30] A. Altomare, M.C. Burla, M. Camalli, G.L. Cascarano, C. Giacovazzo, A. Guagliardi, A.G.G. Moliterni, G. Polidori, R. Spagna, J. Appl. Cryst. 32 (1999) 115-119.

[31] G.M. Sheldrick, SHELxL-97. Program for Crystal Structure Refinement, University of Göttingen, Germany, 1997

[32] MERCURY Program for Crystal Structure Visualisation and Exploration, Version 1.4.2, CCDC, Cambridge, UK. 